\title{
Testing the Autoregressive Cross-Lagged Effects Among Paternal Depression, Affective Parenting and Children's Externalizing Behavior Problems
}

\author{
Youngmi Kim ${ }^{1}$, Hana Song ${ }^{2}$ \\ Department of Child Psychology and Education, Sungkyunkwan University, Seoul, Korea ${ }^{1,2}$ \\ 유아기 자녀를 둔 아버지 우울, 온정적 양육행동, 유아의 외현화 문제행동 \\ 간의 자기회귀교차지연 효과 검증 \\ 김영미 ${ }^{1}$, 송하나 ${ }^{2}$ \\ 성균관대학교 아동·청소년학과 ${ }^{1,2}$
}

\begin{abstract}
Objective: The study examined the longitudinal relationship among paternal depression, affective parenting and children's externalizing behavior problems.

Methods: Data were obtained from the fifth, sixth, and seventh waves of preschooler father cohort $(N=1,694)$ of the Panel Study on Korean Children. Autoregressive cross-lagged model was used to analyze data from the three waves.

Results: The major longitudinal findings are as follows. First, paternal depression, affective parenting and children's externalizing behavior problem were consistently stable over time. Second, paternal prior depression had a significantly negative effect on later affective parenting, and prior affective parenting affect externalizing behavior problems negatively.

Conclusion: The findings showed that paternal prior depression decreases affective parenting and makes children's externalizing behavior problems worse. It highlighted that educational interventions for fathers to get over depression are likely to reduce the negative influence of parenting on children's externalizing behavior problems.
\end{abstract}

Keywords: paternal depression, affective parenting, externalizing behavior problems, autoregressive cross-lagged, longitudinal study

\section{서론}

요즘 사람들은 주변 혹은 매스컴에서 아버지가 아이와 놀아주 고 돌봐주는 모습에 낮설어하지 않는다. 이제 자녀양육은 어 머니만의 몫이 아니라 부모 모두가 참여해야 한다는 가정 내 양성평등 인식이 보편화되어 '홈대디', '프래디', ‘스칸디 대디' 등 아버지 역할에 대한 패러다임이 변하고 있다. 정부 역시 이 러한 흐름에 발맞춰 2016년부터 저출산·고령사회 기본계획

Corresponding Author: Youngmi Kim, Department of Child Psychology and Education, Sungkyunkwan University, 25-2, Sungkyunkwan-ro, Jongnogu, Seoul, Korea

E-mail: nada03001@skku.edu
인 '브릿지플랜(BRIDGE PLAN) 2020'을 실시 중인데 이 중 D 는 Daddy의 약자로 아버지의 육아참여 활성화를 위한 정책들 이 제시되어 있다.

선행 연구들에서도 아버지의 양육참여는 자녀의 학업성취 도와 성취욕구에 긍정적인 영향을 주고 사회 · 정서 · 인지발달 과도 높은 상관이 나타나 유아의 발달에 있어 아버지의 영향력 이 강조되고 있다(Cabrera, Volling, \& Barr, 2018; Lewis \& Lamb, 2003; Tamis-LeMonda, Shannon, Cabrera, \& Lamb, 2004). 특히

(C)The Korean Association of Child Studies

This is an Open Access article distributed under the terms of the Creative Commons Attribution Non-Commercial License (http:// creativecommons.org/licenses/by-nc/4.0) which permits unrestricted noncommercial use, distribution, and reproduction in any medium, provided the original work is properly cited. 
사회적 적응을 위한 토대를 형성하며 전인적 발달에 있어 중요 한 변화가 일어나는 유아기 자녀에게 아버지의 온정적 양육은 더욱 중요하다. 온정적 양육태도는 부모가 자녀에게 애정과 관 심을 표현하고 자녀를 존중해주는 것을 뜻한다(Cho, Lee, Lee, \& Kwon, 1999). 아버지의 양육태도와 자녀 발달과의 관계를 다룬 연구들은 아버지의 온정적이고 애정적인 양육태도는 자 녀의 사회적 유능감을 증가시키고 문제행동은 감소시키는 반 면, 강압적이고 통제적인 양육은 공격적이고 충동적인 행동을 증가시키고 사회적 갈등 상황에서의 해결을 어렵게 하는 것으 로 나타났다(Aunola \& Nurmi, 2005; Denham, Workman, Cole, Weissbrod, Kendziora, \& Zahn-Waxler, 2000)

부모의 양육태도는 유아의 문제행동을 예측하는 것으로 널 리 알려져 있지만, 주로 어머니에만 주목하거나 횡단적으로만 조사하여 아직 아버지의 양육과 자녀의 문제행동에 대하여 밝 혀진 바가 적은 편이다. 또한 유아의 문제 행동에는 일반적으 로 외현적 문제 행동과 내현적 문제 행동이 있는데 어린 유아 의 경우 우울이나 불안이 공격성이나 짜증과 같은 외적인 형 태가 나타나서(Herbert, 2005) 둘 간의 상관이 높은 경향이 있 다. 이에 본 연구에서는 어린 자녀의 외현적 문제행동에 초점 을 맞추어 아버지의 영향력을 살펴보려 하였다.

어머니에 대한 선행 연구들(Chung \& Kim, 2004; Moon, 2007)에서는 특히 어머니의 통제적 양육 행동이 자녀에게 영 향을 미친다는 결과가 지속적으로 보고되어 왔으나 아버지의 경우에는 통제적 행동보다 온정적 양육행동이 자녀의 문제행 동에 영향을 미치는 것으로 나타난 경우가 많았다. 몇몇 선행 연구(Huh \& Bae, 2018; Kerr, Lopez, Olson, \& Sameroff, 2004) 에서, 아버지의 체벌이나 통제적인 양육행동은 자녀의 외현화 문제행동에 영향을 미치지 않은 반면, 애정적이고 온정적인 양육행동은 이후 자녀의 외현화 문제행동을 감소시키는 것으 로 나타났다. 아마 아버지가 어머니보다 양육 참여 시간이 현 저하게 적기 때문에 통제적 양육 행동을 보이기 쉬운 자녀 훈 육에 참여할 시간이 많지 않았을 것으로 생각된다. 따라서 통 제적 양육 행동보다 온정적 양육행동은 유아의 문제행동과 관 련이 높을 것으로 예측된다.

Achenbach와 Rescorla (2000)는 유아의 문제행동을 내재화와 외현화 문제행동의 두 개의 축으로 나뉜 아동용 행동평가척도 (CBCL for 1.5-5 ages)를 통해 정상과 병리사이에 연속성을 가 정하고 증상의 정도와 발달 수준을 고려하여 개인을 평가하는 차원적 접근으로 이해하고자 하였다(Kang \& Oh, 2011). 특히, 유아기에는 자신의 행동을 통제하거나 부정적 정서를 표출하 는데 어려움이 있어 외현화 문제행동을 더욱 빈번하게 보이기
(Gilliom \& Shaw, 2004) 때문에 외현적 문제 행동의 발달적 경 향을 살피는 것은 중요할 것이다. 외현화 문제행동은 주의집중 문제와 공격행동 등 외부로 나타내는 행동으로 자기조절이나 정서표출 규칙 습득 등 발달 과업의 수행을 어렵게 만들며, 이 후 연령이 증가하더라도 증상의 정도가 줄어들지 않고 안정성 을 보인다. 최근 연구에서도 만 5 세 유아의 외현화 문제행동은 6, 7세가 될 때까지 유지되었으며, 4년 후에도 강한 연속성을 보이고 있는 것으로 나타나 조기개입이 중요함을 시사하였다 (Denham et al., 2000; Huh \& Bae, 2018). 따라서 본 연구에서는 아버지의 온정적 양육이 유아의 외현화 문제행동에 미치는 영 향력을 종단적으로 살펴볼 필요가 있을 것으로 보았다. 특히, Combs-Ronto, Olson, Lunkenheimer 과 Sameroff (2009)의 연구 는 유아의 불순응적 문제 행동이 종단적으로 어머니의 부정적 양육 행동을 유의하게 설명하여 부모-자녀 관계에서 양방향적 관계가 있음을 제시하였다. 따라서, 아버지의 온정적 양육 행 동과 유아의 외현적 문제 행동을 종단적으로 검증하여 영향의 방향성을 살펴보는 것이 중요할 것이다.

한편, 성인 우울은 의기소침하거나 활동이 저하되는 심리상 태로 단순한 슬픔에서 일상생활에 어려움을 초래할 정도의 심 한 증상까지 그 범위가 매우 다양하며 보편적이다(Baik, 2009). 보건복지부가 실시한 '2016년도 정신질환사태 역학조사'에 따 르면 성인 중 $1.5 \%$ (약 61만 명)가 일 년 간 우울증상을 겪은 것 으로 나타났다. 또한 전문적인 우울치료를 받는 경우는 캐나 다(46.5\%), 미국(43.1\%), 벨기에(39.5\%) 등에 비해 절반에 겨 우 미치는 $22 \%$ 로 치료해야 할 질병임에도 전문가의 도움을 받 지 않은 채 방치되어 있다. 우울한 사람은 인지적 왜곡과 자신 에 대한 부정적 평가로 인해 역기능적 대인관계를 보이게 되는 데 이는 가족관계 안에서 더 빈번히 발생하여 부모가 자녀를 대하는 방식에 있어서 많은 문제를 보인다. 선행연구들은 우 울한 부모가 어린 자녀의 반항 행동에 대해 비일관적인 훈육을 하고 확고하지 않은 태도를 보인다는 것을 밝혀왔다(Lovejoy, Graczyk, O’Hare, \& Neuman, 2000; Marchand \& Hock, 1998).

특히 아버지의 우울은 자녀에게 직접적인 영향을 미치기도 하지만 자녀양육방식을 통해 문제행동에 영향을 미치며, 그 영향력이 어머니 우울보다 더 클 수도 있어 아버지의 우울에 대한 관심이 증가하고 있다(Elgar, Mills, McGrath, Waschbusch, \& Brownridge, 2007; Marchand \& Hock, 2003; Phares, Duhig, \& Watkins, 2002; Rutter, 1990). 우울한 아버지는 자녀와 신 체적 접촉을 적게 하면서 시간을 보내고(Lyons-Ruth, Wolfe, Lyubchik, \& Steingard, 2002), 자신의 기분상태에 따라 비일관 적이고 온정적이지 않은 행동을 보인다(Wong et al., 2005). 또 
한 무기력하고 활력이 없어 엄격하고 통제적으로 자녀를 대하 기보다는 무관심하고 자녀의 행동에 덜 반응적이고 덜 온정적 인 양육태도를 보이게 된다. 이러한 아버지의 양육행동은 유 아로 하여금 공격성이나 주의집중 문제와 같은 문제행동을 불 러일으키고, 아버지는 이런 행동을 통제하기 위하여 더 강압 적으로 반응하거나 무시하면서 다시 악순환의 과정을 거치게 된다(Patterson, 2002; Ramchandani, Stein, Evans, \& O'connor, 2005). 국내 연구들(Chung \& Chun, 2005; Jang, Kim, Kim, 2011)에서도 아버지의 우울은 유아의 문제 행동과 직접 관련 이 있었을 뿐 아니라 긍정적 양육 행동과 부정적 양육 행동 모 두에 영향을 미치는 것으로 나타났다. 또한 아버지의 양육 참 여나 스트레스가 어머니와의 상호작용에 영향을 미쳐 유아의 문제 행동에 영향을 주는 경향이 있었다( J. Kim \& Lee, 2005; Park, \& Lim, 2000). Elgar 등(2007)의 종단연구에서도 우울한 아버지는 그렇지 않은 아버지에 비해 자녀에게 덜 온정적이 고 방임적인 양육태도를 보였으며 이것은 유아의 외현화 문제 를 가져오는 것으로 나타났다. 이러한 연구들은 아버지의 우 울이 양육태도와 자녀의 외현화 문제행동에 지속적으로 영향 을 미칠 수 있음을 시사한다. 한편, 유아의 문제행동이 아버지 로부터 특정 유형의 반응과 정서를 유도해내는 양방향적 관계 를 배제할 수는 없다. 예를 들어 유아의 적대적이고 불순응적 행동은 자녀에 대한 부모의 부정적 정서를 증가시키고 애정 적인 양육방식을 보이지 않게 할 수 있다(Fendrich, Warner, \& Weissman, 1990; Ramchandani et al., 2005). 그러나 유아의 문 제행동을 다룬 연구들(Dishion, Shaw, Connell, Gardner, Weaver, \& Wilson, 2008; Gardner, Sonuga-Barke, \& Sayal, 1999)은 유아 의 문제행동에 있어 부모의 특성에 대한 이해가 선행되어야 함을 강조하였으며 가족 중심의 치료적 개입이 가장 효율적임 을 밝혀왔다. Gardner 등(1999)의 연구에서는 부모에게 문제 상황에서 자녀와의 긍정적 상호작용 전략을 터득하게 했을 때 2 년 뒤 자녀의 문제 행동을 유의미하게 감소시켰다. 따라서 본 연구에서는 아버지의 특성과 유아의 문제행동에 대해 양방향 적 관계가 아닌 순차적 인과관계로 설정하여 살펴보고자 하였 다. 특히 초기 아동기에는 발달속도가 빠르며, 아버지의 특성 과 유아의 문제행동의 관계 역시 시간의 흐름에 따라 변하기 때문에 시간에 따른 잠재적 변화와 인과관계를 종단적으로 살 펴보는 것이 중요하다(Verhoeve, Junger, Van Aken, Dekovic, \& Van Aken, 2010). 따라서 본 연구에서는 아버지 우울, 온정적 양육행동, 유아의 외현화 문제행동을 세 시점에서 측정하여 이전 시점의 세 변인이 이후 시점의 세 변인에 어떠한 영향을 주는지 시간의 흐름에 따른 안정성과 인과관계를 구체적으로
검증함으로써 변인들 간의 관련성을 보다 깊이 있게 이해하고 자 하였다. 본 연구의 연구문제는 다음과 같다.

\section{연구문제 1}

아버지의 우울, 온정적 양육행동과 유아의 외현화 문제행동은 시간이 흐름에 따라 유지되는가?

\section{연구문제 2}

아버지의 우울, 온정적 양육행동과 유아의 외현화 문제행동 간 인과관계는 어떠한가?

\section{연구방법}

\section{연구대상}

본 연구에서는 육아정책연구소에서 실시한 한국아동패널연 구(Panel Study on Korean Children [PSKC])의 3개년도 자료(5 차-7차)를 활용하였다. 본 연구에서 사용된 사례수는 세 개년 도에 1 회 이상 조사에 참여한 유아와 아버지 1,694쌍이며, 6 차 년도를 기준으로 아버지의 평균 연령은 만 38.56세 $(S D=3.96)$ 이었다. 유아의 평균 월령은 62.68개월 $(S D=1.34$, Range = 6066)이며, 성별은 남아 859명(50.7\%), 여아 835명(49.3\%)으로 구성되어 있었다.

\section{연구도구}

\section{아버지 우울}

아버지의 우울은 한국아동패널 연구진이 K6 우울척도(Kessler, Andrew, Cople, Hiripi, Mroczek, Normand, Walters, \& Zaslavsky, 2002)를 수정한 척도를 사용하였다. 본 설문지는 Likert식 5점 척도로 총 6 문항으로 구성되어 있으며 총점으로 분석에 사용 하였다. 총점이 높을수록 우울 정도가 높다는 것을 의미하며, 차수별 신뢰도계수(Cronbach' $\alpha$ )는 5차년도 .91, 6차년도 .92, 7차년도 .93으로 나타났다.

\section{아버지 온정적 양육행동}

아버지의 양육행동은 한국아동패널 연구진이 Cho 등(1999) 의 문항을 참고하여 수정한 양육실제의 두 개의 하위요인(통 
제, 온정) 중 온정적 양육행동에 해당하는 6 문항의 점수를 합 산하여 사용하였다. 본 설문지는 5점 척도이며, 점수가 높을수 록 온정적 양육행동이 높은 것을 의미한다. 본 척도의 차수별 신뢰도계수(Cronbach' $\alpha$ )는 5차년도 .86, 6차년도 .88, 7차년도 .87 로 나타났다.

\section{유아의 외현화 문제행동}

유아의 문제행동은 Achenbach와 Rescorla (2000)가 개발하고 Oh와 Kim (2009)이 표준화한 아동행동평가척도(Child Behavior Checklist [CBCL] 1.5-5) 중 외현화 문제행동에 해당되는 주 의집중 문제(5문항)와 공격적 행동(19문항)의 하위요인을 합 산하여 사용하였다. 어머니가 3점 척도로 응답하며, 점수가 높 을수록 외현화 문제행동이 높은 것을 의미한다. 본 척도의 차 수별 신뢰도계수(Cronbach' $\alpha$ )는 5차년도 .88, 6차년도 .88, 7 차년도 .88로 나타났다.

\section{자료분석}

시간에 따른 아버지 우울, 온정적 양육행동, 유아의 외현적 문 제행동 간의 인과관계를 종단적으로 살펴보기 위하여 $\mathrm{AMOS}$ 18.0 (IBM Co., Armonk, NY) 프로그램을 이용하여 자기회귀교 차지연모형(Autoregressive cross-lagged model [ARCL])을 설정 하여 분석을 실시하였다. 자기회귀모형은 특정 시점에서의 값 이 이전 시점의 값에 의해 설명된다는 가정으로 본 연구에서 는 아버지 우울, 온정적 양육행동, 유아의 외현적 문제행동을 잠재변수로 설정하였다. 잠재변수는 시간에 따라 변하지 않는 측정 불변성을 지니며 측정오차를 통제한 뒤 이론적 개념 간 관계를 통계적으로 추정할 수 있다는 장점이 있다(Hong, Park, $\&$ Kim, 2007).

검증모형의 적합도를 평가하기 위해 $\chi^{2}$ 값과 절대적합지수 RMSEA와 증분적합지수 CFI, TLI를 확인하였다. 표본의 크 기에 민감한 $\chi^{2}$ 값은 표본의 크기가 클수록 유의미한 차이가 나올 수 있다는 단점이 있어 다른 적합지수를 활용하여 모형 의 적합도를 판단하였다. TLI와 CFI는 일반적으로 .90이상이 면 적합도가 좋은 것으로 평가하며, RMSEA는 .06이하이면 좋 은 적합도로 평가된다(Hu \& Bentler, 1999). 결측치 처리를 위 해 완전정보 최대우도법(full-information maximum likelihood [FIML])을 사용하였다.

\section{연구결과}

\section{주요 변인들의 기술통계 및 상관분석}

본 연구에서 사용된 변인들의 기술통계는 Table 1 에 제시하였 다. 아버지의 우울과 온정적 양육행동은 세 시점에 걸쳐 비슷 한 수준을 보였으며, 유아의 외현화 문제행동은 연령이 증가함 에 따라 점차 감소하는 것으로 나타났다. 왜도의 절대값은 2 미 만, 첨도는 4 미만으로 나타나 정규성 조건을 충족하는 것을 확 인하였다. Pearson 상관분석 결과(Table 2), 변인들 간 상관은 동 일한 측정시기와 측정시기 간에 모두 유의미하였다 $(p<.01)$.

\section{자기회귀교차지연모형 검증}

자기회귀 교차지연 모형을 분석하기 위해서는 각 시점에서 측 정한 개념이 동일한 개념에 대한 측정인가를 분석하는 측정 동 일성, 잠재변수의 회귀계수가 시간에 따라 동일한지를 검증하 는 경로 동일성, 그리고 오차공분산 동일성이 성립해야 한다 ( J. Kim, Kim, \& Hong, 2009). 이에 본 연구에서는 기저 모형과 8 개의 경쟁모형을 설정하여 측정 동일성, 경로 동일성, 오차 공 분산 동일성을 검증하고 가장 간명하고 설명력 있는 모형을 찾 고자 하였다. 모형 2 는 측정동일성 검증, 모형 3 부터 7 은 경로 동일성 검증, 모형 8 은 오차공분산 검증을 위한 모형이다.

모형 1: 아무런 제약을 가하지 않은 모형

모형 2: 잠재변수들에 대한 요인 적재치를 시점별로 동일하 게 제약을 가한 모형

모형 3: 아버지 우울의 자기회귀계수에 동일성 제약을 가한 모형

모형 4: 아버지 온정적 양육행동의 자기회귀계수에 동일성 제약을 가한 모형

모형 5: 유아의 외현화 문제행동의 자기회귀계수에 동일성 제약을 가한 모형

모형 6: 아버지 우울의 교차회귀계수에 동일성 제약을 가한 모형

모형 7: 아버지 온정적 양육행동의 교차회귀계수에 동일성 제약을 가한 모형

모형 8: 아버지 우울, 온정적 양육행동, 유아의 문제행동의 오차공분산 간에 동일성 제약을 가한 모형

위의 8 개의 모형 중 최적의 모형을 찾기 위해 모형 1 에서 8 까지 순차적으로 비교하였다. 모형의 판단 기준으로 $\chi^{2}$ 검증 
Table 1

Descriptive Statistics of Variables

\begin{tabular}{|c|c|c|c|c|}
\hline & $M$ & $S D$ & Skewness & Kurtosis \\
\hline \multicolumn{5}{|c|}{ Paternal depression } \\
\hline wave 1 & 11.18 & 4.04 & .70 & .65 \\
\hline wave 2 & 10.98 & 3.96 & .66 & .45 \\
\hline wave 3 & 11.22 & 4.45 & .98 & 1.48 \\
\hline \multicolumn{5}{|c|}{ Paternal affective parenting } \\
\hline wave 1 & 21.25 & 3.55 & -.15 & .36 \\
\hline wave 2 & 21.72 & 3.79 & -.20 & .42 \\
\hline wave 3 & 21.06 & 3.52 & -.23 & .54 \\
\hline \multicolumn{5}{|c|}{ Externalizing behavior problem } \\
\hline wave 1 & 7.77 & 5.83 & .76 & .11 \\
\hline wave 2 & 6.33 & 5.52 & 1.06 & .80 \\
\hline wave 3 & 5.67 & 5.32 & 1.25 & 1.60 \\
\hline
\end{tabular}

Table 2

Correlations of Analyzed Variables

\begin{tabular}{|c|c|c|c|c|c|c|c|c|c|}
\hline & 1 & 2 & 3 & 4 & 5 & 6 & 7 & 8 & 9 \\
\hline 1 & - & & & & & & & & \\
\hline 2 & $.44^{* *}$ & - & & & & & & & \\
\hline 3 & $.43^{* *}$ & $.44^{* *}$ & - & & & & & & \\
\hline 4 & $-.24^{* *}$ & $-.23^{* *}$ & $-.19^{* *}$ & - & & & & & \\
\hline 5 & $-.15^{* *}$ & $-.28^{* *}$ & $-.17^{* *}$ & $.51^{* *}$ & - & & & & \\
\hline 6 & $-.17^{* *}$ & $-.24^{* *}$ & $-.30^{* *}$ & $.48^{* *}$ & $.52^{* *}$ & - & & & \\
\hline 7 & $.12^{* *}$ & $.07^{* *}$ & $.11^{* *}$ & $-.15^{* *}$ & $-.12^{* *}$ & $-.11^{* *}$ & - & & \\
\hline 8 & $.11^{* *}$ & $.15^{* *}$ & $.13^{* *}$ & $-.15^{* *}$ & $-.18^{* *}$ & $-.14^{* *}$ & $.59^{* *}$ & - & \\
\hline 9 & $.09^{* *}$ & $.13^{* *}$ & $.15^{* *}$ & $-.16^{* *}$ & $-.14^{* *}$ & $-.16^{* *}$ & $.55^{* *}$ & $.65^{* *}$ & - \\
\hline
\end{tabular}

Note. $N=1,694$. 1=paternal depression w1; 2=paternal depression w2; 3=paternal depression w3; 4=paternal affective parenting w1; 5 =paternal affective parenting w2; 6=paternal affective parenting w3; 7=children's externalizing behavior problems w1; 8=children's externalizing behavior problems w2; 9=children's externalizing behavior problems w3.

${ }^{* *} p<.01$.

을 적용할 수 있지만, 이 검증은 모델의 복잡성과 표본 크기에 민감하므로 RMSEA와 CFI, TLI를 이용하여 보완하였다. 또 한 TLI와 RMSEA가 동일화 제약을 가한 후에 이전에 비해 좋 아지거나 동일하고, $\mathrm{CFI}$ 는 이전에 비해 .01 이내로 좋아지거 나 나빠져도 동일성 제약이 기각되지 않는 점(Cheung \& Rensvold, 2002)을 참고하여 최적의 모형을 검증하였다. 8개 모형 에 대한 모형비교 결과는 Table 3과 같다.

기저모형인 모형 1 과 측정동일성 가정에 따라 각각의 측정 변수 요인 적재치를 시간에 따라 동일하게 제약한 모형 2의 비 교 결과, TLI와 RMSEA는 근소하게 증가했고, $\mathrm{CFI}$ 의 차이가 없어 시간에 따른 측정동일성이 충족되었다. 이는 아버지가
시간의 흐름에 따라 우울, 온정적 양육행동, 유아의 외현화 문 제행동에 대한 해석을 동일하게 하는 것을 나타낸다. 각 변수 의 자기회귀계수에 대해 동일성 제약을 가한 모형 $3,4,5$ 는 모 형 2와 비교했을 때 TLI와 RMSEA는 같았고, CFI는 차이가 없 어 자기회귀 계수는 시간에 따라 동일하였다. 즉, 아버지 우울, 온정적 양육행동, 유아의 외현화 문제행동의 5차 년도(T-1) 값 이 6차 년도(T)에 주는 영향력의 정도가 6차 년도(T) 값이 7차 년도 $(\mathrm{T}+1)$ 에 주는 영향력의 정도가 동일한 것으로 나타났다. 모형 6과 7은 매 시점에서 교차회귀계수에 동일성을 가한 모 형인데 TLI와 RMSEA는 같았고, CFI의 차이가 없어 경로 동 일성이 성립됨을 확인하였다. 이는 아버지 우울의 온정적 양 
Table 3

Results of Fit Statistics for Competing Autoregressive Cross-Lagged Models

\begin{tabular}{|c|c|c|c|c|c|c|}
\hline Models & $\chi^{2}$ & $d f$ & CFI & TLI & RMSEA & $\Delta \chi^{2}$ \\
\hline 1 & 3470.06 & 758 & .934 & .922 & .041 & - \\
\hline 2 & 3498.77 & 780 & .934 & .924 & .040 & 28.71 \\
\hline 4 & 3506.25 & 782 & .934 & .924 & .040 & 5.68 \\
\hline 5 & 3507.27 & 783 & .934 & .924 & .040 & 1.02 \\
\hline 8 & 3517.48 & 788 & .934 & .924 & .040 & 8.42 \\
\hline
\end{tabular}

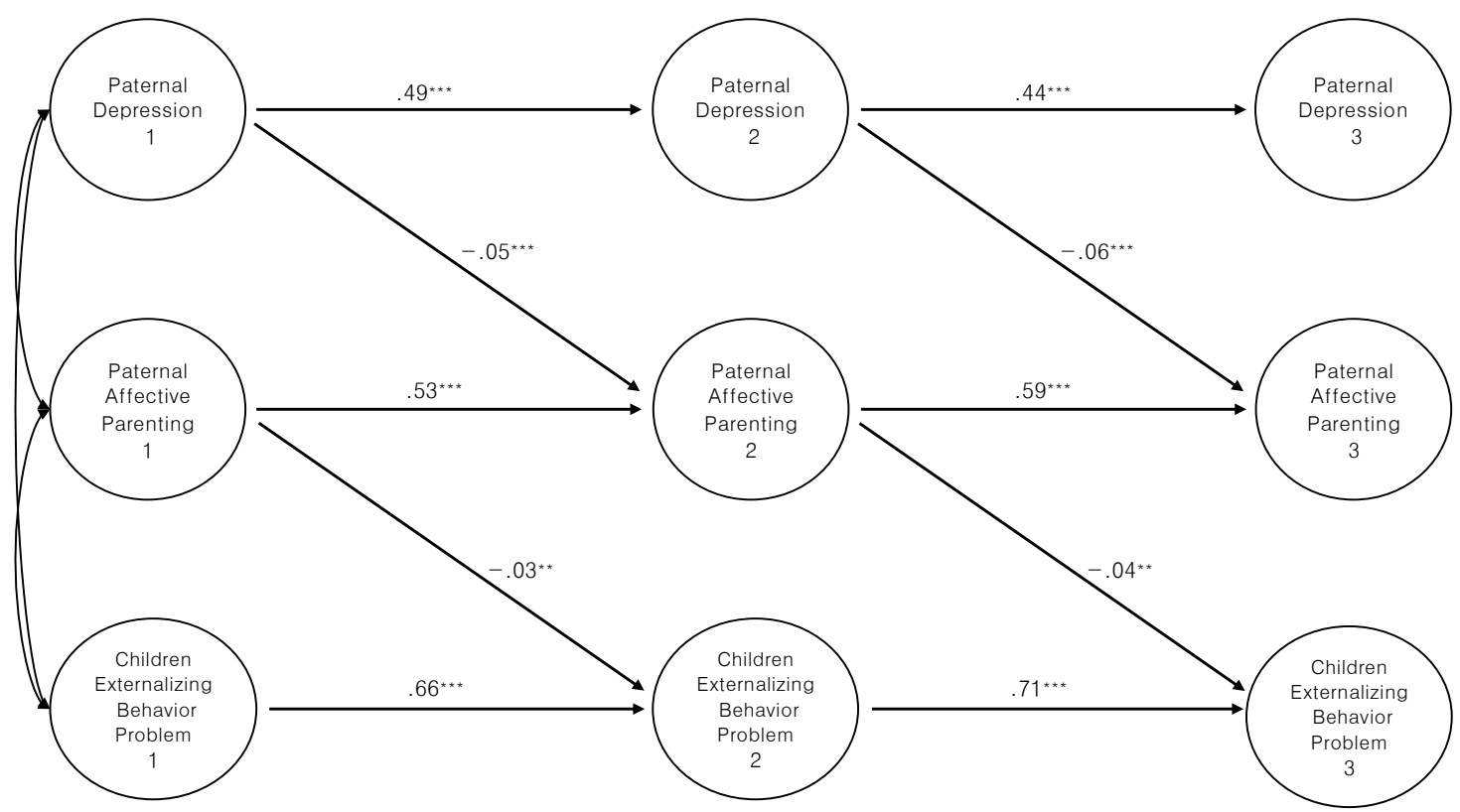

Figure 1. The longitudinal relationship between paternal depression, affective parenting and children's externalizing behavior problems. Numbers on paths are standardized regression coefficients.

${ }^{* *} p<.01{ }^{* * *} p<.001$.

육행동에 대한 교차지연회귀효과와 아버지 온정적 양육행동 의 외현화 행동에 대한 교차지연회귀효과가 시간의 흐름에 따 라 동일하다는 것을 의미한다. 마지막으로 모형 8은 오차 공분 산을 동일하게 제약한 모형으로 적합도에 문제가 없었다. 결 론적으로 동일화 제약이 추가되어도 모형의 적합도가 나빠지 지 않으므로 가장 간명한 모형 8을 최종모형으로 결정하였다. 동일화 제약을 가장 많이 가한 최종모형 8 의 적합도는 $\mathrm{CFI}=$ $.934, \mathrm{TLI}=.924, \mathrm{RMSEA}=.040$ 으로 권장수용기준에 맞는 괜 찮은 적합도를 나타냈다. 모형 8에 대한 표준화된 구조계수의 추정치는 Figure 1에 제시하였다.

먼저, 아버지 우울, 온정적 양육행동과 유아의 외현화 문제 행동이 시간의 경과에 따라 안정적으로 유지되는지 살펴본 결
과, 세 시점 $(5,6,7$ 차년도)에 걸쳐 모두 통계적으로 유의미한 영향을 미치는 것으로 나타났다. 즉, 3 년이라는 시간 동안 이전 시점이 이후 시점에 정적으로 영향을 미쳤으며, 특히 유아의 외현화 문제행동은 그 영향력이 매우 큰 것으로 나타났다. 따 라서 아버지 우울, 온정적 양육행동과 유아의 외현화 문제행동 은 시간의 경과에도 안정적으로 지속되는 것임을 알 수 있다.

다음으로, 아버지 우울, 온정적 양육행동과 유아의 외현화 문제행동 간 인과관계를 회기의 경과에 따라 살펴보았다. 교 차지연 계수의 추정치를 확인한 결과, 5차 아버지 우울에서 6 차 온정적 양육행동으로의 경로 $(\beta=-.05, p<.001), 6$ 차 아버지 우울에서 7차 온정적 양육행동으로의 경로 $(\beta=-.06, p<.001)$ 가 모두 부적으로 유의하였다. 시간이 흐름에 따라 교차지연 
계수가 부적으로 유의미하게 유지된다는 것은 아버지 우울이 이후의 온정적 양육행동을 낮추는 영향관계가 일관됨을 보여 준다. 다음으로 5 차 아버지 온정적 양육에서 6차 유아의 외현 화 문제행동으로의 경로 $(\beta=-.03, p<.01), 6$ 차 아버지 온정적 양육에서 7차 유아의 외현화 문제행동으로의 경로 $(\beta=-.04, p$ <.01) 모두 부적으로 유의하였다. 이는 아버지의 온정적 양육 행동은 이후의 유아의 외현화 문제행동을 낮추는 영향관계가 일관된다는 것을 의미한다. 또한 5차년도 아버지 우울은 6차 년도 온정적 양육행동에, 이것은 다시 7차년도 유아의 외현화 문제행동에 유의한 영향을 미쳤다. 이러한 결과는 아버지의 우울은 온정적 양육행동에 영향을 미치는 직접적인 원인변인 이며, 이것이 다시 자녀의 문제행동으로 이어질 가능성이 높 음을 의미한다.

\section{논의 및 결론}

본 연구는 한국아동패널의 5차(2012), 6차(2013), 7차(2014) 데 이터를 활용하여 유아기 자녀를 둔 아버지의 우울, 온정적 양 육행동, 유아의 외현화 문제행동 변인들의 시간의 흐름에 따 른 안정성과 인과관계를 알아보고자 하였으며 그 결과는 다음 과 같다.

첫째, 아버지의 우울, 온정적 양육행동, 유아의 외현화 문제 행동은 모두 시간의 경과에 따라 안정적으로 정적인 영향을 예측하는 것으로 나타났다. 한국아동패널의 표본은 전국에서 층화표집으로 이루어졌기 때문에 유아가 4-6세에 이르기까지 직접적인 개입이 있지 않은 이상 아버지의 우울과 양육행동은 비슷한 수준으로 유지되고, 유아 역시 유사한 수준의 외현화 문제행동을 안정적으로 유지한다는 것을 의미한다.

아버지의 지속적인 우울감은 자신에 대해 부정적으로 인식 하여 정서, 인지, 동기, 생리적으로 무력한 상태에 달해 일상적 기능수행이나 대인관계에서 어려움을 겪게 할 뿐만 아니라 자 녀와의 상호작용이나 양육태도에 부정적인 영향을 미치게 한 다(Davis, Davis, Freed, \& Clark, 2011; Wilson \& Durbin, 2010). 또한 자녀가 영유아 시기일 때 부모의 우울이 가장 높게 나타 난다는 연구결과(Dave, Peterson, Sherr, \& Nazareth, 2010)를 고 려할 때, 아버지의 우울 치료 및 심리적 안녕감을 위한 제도적 개입을 통해 연속성의 고리를 끊어줄 필요가 있다. 다음으로 아버지의 온정적 양육행동은 우울에 비해 안정성이 높은 것으 로 나타났다. 아버지의 온정적이지 않은 양육행동은 자녀와의 역기능적 상호작용을 유발하고 강압적이고 부정적인 양육태
도를 유지하게 한다. 과거에 비해 가족 구조의 변화와 양성평 등 인식의 보편화 등으로 가정 내 아버지 역할이 증대되고 이 에 맞춰 정부에서도 아버지를 위한 정책을 내고 있지만 여전 히 부족한 실정이다. 따라서 초기 유아기 자녀를 둔 아버지를 위한 양육코칭과 프로그램이 확산될 필요가 있다.

유아의 외현화 문제행동은 다른 변인들에 비해 이후 시점 에 미치는 영향력이 큰 것으로 나타났다. 초기 유아기에는 의 사소통을 하는 대상이 또래로 확장되고 교육기관에 다니면서 사회적 기술과 규범을 습득하는 시기이다. 이 과정에서 유아 들은 많은 어려움과 좌절을 경험하기도 하고 여러 가지 문제 행동이 발생하기도 한다. 발달적으로 이 시기에 발생하는 문 제들은 시간이 지나면서 자연스럽게 해결되는 것들이 많지 만, 문제행동이 심한 경우에는 다른 발달과업의 성취에 부정 적인 영향을 미치고 이후 학령기의 일탈과 비행행동, 성인기 의 심리·사회적 문제에까지 영향을 미친다(Greenberg, Speltz, \& Deklyen, 1993; Leblanc et al., 2008). 따라서 유아기에 나타난 심각한 외현화 문제행동은 자발적으로 쉽게 완화될 수 없는 문제임을 미뤄볼 때, 외현화 문제행동의 정도와 지속성을 고 려한 조기 개입과 치료가 필요하다고 볼 수 있다.

둘째, 이전 시점의 아버지 우울은 이후 시점의 온정적 양육 행동에 부적으로 유의한 영향을 미치고, 이전 시점의 온정적 양육행동은 이후 시점의 외현화 문제행동에 부적으로 유의한 영향을 미치는 부정적 인과관계가 나타났다. 이는 아버지의 우울은 자녀에 대한 온정적 양육방식을 감소시키는 직접적인 원인이며, 이러한 양육행동이 자녀의 문제행동을 강화시키는 결과를 가져오는 것을 의미한다. 다시 말해, 아버지의 온정적 양육행동은 자녀의 외현화 문제행동을 감소시키는 효과가 있 으며, 온정적 양육행동을 증진시키기 위해서는 아버지가 자신 의 우울을 자녀에게 투사하지 않고 해소하여 심리적 건강함을 유지해야 함을 알 수 있다. 그러나 본 연구 결과에서 표준화 회 귀계수가 매우 작게 나타났으며, 아버지를 대상으로 한 종단 연구가 적다는 점을 고려할 때 아버지 우울, 양육행동, 유아의 문제행동 간의 인과관계에 대한 결과를 일반화하기 위해서는 추후연구가 더 필요할 것으로 생각된다.

본 연구의 교차지연계수의 크기를 비교했을 때, 아버지 의 우울이 온정적 양육행동에 미치는 영향력이 아버지의 온 정적 양육행동이 유아의 외현화 문제행동에 미치는 영향력 보다 더 큰 것으로 확인되었다. 우울한 사람들은 부정적으 로 왜곡된 인지 처리과정을 가지고 자신과 주변에 대한 부정 적 사고를 가져 역기능적 대인관계를 보이기 때문에(Abela \& D'Alessandro, 2002) 자녀를 대하는 방식에 있어 많은 문제를 
보일 수 있다. 또한 우울한 아버지는 무기력하고 기분상태에 따라 비일관적인 행동을 보이고 자녀와의 신체적 접촉을 적게 하기 때문에(Lyons-Ruth, Wolfe, Lyubchik, \& Steingard, 2002; Wong et al., 2005). 자녀에게 덜 반응적이고 덜 온정적인 양육 태도를 보일 수 있다. 선행연구들(Dishion et al., 2008; Gardner et al., 1999)에서도 부모-자녀의 긍정적 상호작용과 양육행동 이 자녀의 문제 행동을 예방하는 가장 효율적인 방법이라는 것을 밝혀왔다. 따라서 유아의 외현화 문제행동을 줄이기 위 하여 유아 자체에만 초점을 두는 것에서 확대하여 아버지가 우울에서 벗어나 온정적 양육행동을 가질 수 있는 지지체계를 구축하는 것이 필요하다. 특히, 부부 관계가 부모-자녀 관계에 영향을 준다는 사실은 널리 알려져 있으므로, 안정적인 배우 자 관계 및 배우자의 적극적 지지가 아버지 정신건강의 중요 한 보호 요인으로 작용할 수 있을 것이다.

본 연구의 제한점과 제언은 다음과 같다. 첫째, 본 연구에 서 유아의 외현화 문제행동을 제외한 아버지 우울과 양육행동 은 한국아동패널에서 제공하는 적은 문항으로 구성된 척도를 활용했기 때문에 내용 및 구성 타당도를 확보했다고 단정하기 어렵다. 이러한 자료가 이후 아버지-자녀 상호작용 관찰을 통 해 재검증 되어 타당성을 보완할 필요가 있다. 둘째, 부모의 통 제적 양육 행동과 문제 행동 간의 관계가 선행 연구에서 널리 검증되었으나, 본 연구에서는 자료의 제한으로 아버지의 온정 적 양육 행동만을 다룬 한계가 있다. 이후 연구에서는 통제적 양육 행동을 포함한 아버지의 다양한 양육 행동 유형을 고려 하여 자녀의 문제 행동에 가장 결정적으로 영향을 주는 양육 패턴을 찾는 것이 필요할 것이다. 마지막으로, 본 연구에서는 변인들 간의 일방향적인 인과관계만을 검증하여 변인들 간의 상호적 인과관계에 대해서는 확인할 수 없었다. 따라서 추후 연구에서는 아버지와 자녀 간의 상대방 효과를 검증하는 인과 적 연구가 지속적으로 이루어져야할 것이다. 또한 아버지 뿐 아니라 어머니의 양육 행동이나 정신병리적 속성 등을 함께 고려하여 다양한 상호작용 효과와 유아에 대한 영향의 방향을 살필 필요가 있을 것이다.

\section{Notes}

This article was presented at the 8th International Conference of the Panel Study on Korean Children.

\section{Conflict of Interest}

No potential conflict of interest relevant to this article was reported.

\section{References}

\section{In English}

Abela, J. R., \& D’Alessandro, D. U. (2002). Beck's cognitive theory of depression: A test of the diathesis-stress and causal mediation components. British Journal of Clinical Psychology, 41(2), 111-128. doi:10.1348/014466502163912

Achenbach, T. M., \& Rescorla, L. A. (2000). Manual for the ASEBA preschool forms \& profiles. Burlington, VT: University of Vermont, Research Center for Children, Youth, \& Families.

Aunola, K., \& Nurmi, J.-E. (2005). The role of parenting styles in children's problem behavior. Child Development, 76(6), 1144-1159. doi:10.1111/j.1467-8624.2005.00840.x-i1

Cabrera, N. J., Volling, B. L., \& Barr, R. (2018). Fathers are parents, too! Widening the lens on parenting for children's development. Child Development Perspectives, O(0) 1-6. doi:10.1111/cdep.12275

Cheung, G. W., \& Rensvold, R. B. (2002). Evaluating goodnessof-fit indexes for testing measurement invariance. Structural Equation Modeling: A Multidisciplinary Journal, 9(2), 233255. doi:10.1207/S15328007SEM0902_5

Combs-Ronto, L. A., Olson, S. L., Lunkenheimer, E. S., \& Sameroff, A. J. (2009). Interactions between maternal parenting and children's early disruptive behavior: Bidirectional associations across the transition from preschool to school entry. Journal of Abnormal Child Psychology, 37(8), 1151-1163. doi:10.1007/s10802-009-9332-2

Dave, S., Petersen, I., Sherr, L., \& Nazareth, I. (2010). Incidence of maternal and paternal depression in primary care: A cohort study using a primary care database. Archives of Pediatrics and Adolescent Medicine, 164(11), 1038-1044. doi:10.1001/archpediatrics.2010.184

Davis, R. N., Davis, M. M., Freed, G. L., \& Clark, S. J. (2011). Fathers' depression related to positive and negative parenting behaviors with 1 -year-old children. Pediatrics, 127(4), 612-618. doi:10.1542/peds.2010-1779

Denham, S. A., Workman, E., Cole, P. M., Weissbrod, C., Kendziora, K. T., \& Zahn-Waxler, C. (2000). Prediction of externalizing behavior problems from early to middle childhood: The role of parental socialization and emotion expression. Development and Psychopathology, 12(1), 23-45. doi:10.1017/S0954579400001024

Dishion, T. J., Shaw, D., Connell, A., Gardner, F., Weaver, C., \& 
Wilson, M. (2008). The family check-up with high-risk indigent families: Preventing problem behavior by increasing parents' positive behavior support in early childhood. Child Development, 79(5), 1395-1414. doi:10.1111/j.14678624.2008.01195.x

Elgar, F. J., Mills, R. S. L., McGrath, P. J., Waschbusch, D. A., \& Brownridge, D. A. (2007). Maternal and paternal depressive symptoms and child maladjustment: The mediating role of parental behavior. Journal of Abnormal Child Psychology, 35(6), 943-955. doi:10.1007/s10802007-9145-0

Fendrich, M., Weissman, M. M., \& Warner, V. (1990). Screening for depressive disorder in children and adolescents: Validating the center for epidemiologic studees depression scale for children. American Journal of Epidemiology, 131(3), 538-551. doi:10.1093/oxfordjournals.aje.a115529

Gardner, F. E., Sonuga-Barke, E. J. S., \& Sayal, K. (1999). Parents anticipating misbehaviour: An observational study of strategies parents use to prevent conflict with behaviour problem children. The Journal of Child Psychology and Psychiatry and Allied Disciplines, 40(8), 1185-1196. doi:10.1111/1469-7610.00535

Gilliom, M., \& Shaw, D. S. (2004). Codevelopment of externalizing and internalizing problems in early childhood. Development and Psychopathology, 16(2), 313-333. doi:10.1017/S0954579404044530

Greenberg, M. T., Speltz, M. L., \& Deklyen, M. (1993). The role of attachment in the early development of disruptive behavior problems. Development and Psychopathology, 5(12), 191-213. doi:10.1017/S095457940000434X

Herbert, M. (2005). Developmental problems of childhood and adolescence: Prevention, treatment and training. Malden, MA: Blackwell Publication.

Hu, L., \& Bentler, P. M. (1999). Cutoff criteria for fit indexes in covariance structure analysis: Conventional criteria versus new alternatives. Structural Equation Modeling: A Multidisciplinary Journal, 6(1), 1-55. doi:10.1080/10705519909540118

Kerr, D. C. R., Lopez, N. L., Olson, S. L., \& Sameroff, A. J. (2004). Parental discipline and externalizing behavior problems in early childhood: The roles of moral regulation and child gender. Journal of Abnormal Child Psychology, 32(4), 369383. doi:10.1023/B:JACP.0000030291.72775.96

Kessler, R. C., Andrews, G., Colpe, L. J., Hiripi, E., Mroczek, D. K., Normand, S. L., . . . \& Zaslavsky, A. M. (2002). Short screening scales to monitor population prevalences and trends in non-specific psychological distress. Psychological Medicine, 32(6), 959-976. doi:10.1017/ S0033291702006074

Leblanc, N., Boivin, M., Dionne, G., Brendgen, M., Vitaro, F., Tremblay, R. E., \& Perusse, D. (2008). The development of hyperactive-impulsive behaviors during the preschool years: The predictive validity of parental assessments. Journal of Abnormal Child Psychology, 36(7), 977-987. doi:10.1007/ s10802-008-9227-7

Lewis, C., \& Lamb, M. E. (2003). Fathers' influences on children's development: The evidence from two-parent families. European Journal of Psychology of Education, 18(2), 211 228. Retrieved from http://eprints.lancs.ac.uk/18775/

Lovejoy, M. C., Graczyk, P. A., O’Hare, E., \& Neuman, G. (2000). Maternal depression and parenting behavior: A metaanalytic review. Clinical Psychology Review, 20(5), 561-592. doi:10.1016/S0272-7358(98)00100-7

Lyons-Ruth, K., Wolfe, R., Lyubchik, A., \& Steingard, R. (2002). Depressive symptoms in parents of children under age 3: Sociodemographic predictors, current correlates, and associated parenting behaviors. In K. T. McLearn, \& M. A. Schuster (Eds.), Child rearing in America: Challenges facing parents with young children (pp. 217-259). New York: Cambridge University Press. doi:10.1017/ CBO9780511499753.008

Marchand, J. F., \& Hock, E. (1998). The relation of problem behaviors in preschool children to depressive symptoms in mothers and fathers. Journal of Genetic Psychology, 159(3), 353-366. doi:10.1080/00221329809596157

Patterson, G. R. (2002). The early development of coercive family process. In J. B. Reid, G. R. Patterson, \& J. Snyder (Eds.), Antisocial behavior in children and adolescents: $A$ developmental analysis and model for intervention (pp. 2544). Washington, DC: American Psychological Association. doi:10.1037/10468-002

Phares, V., Duhig, A. M., \& Watkins, M. M. (2002). Family context: fathers and other supports. In S. H. Goodman \& I. H. Gotlib (Eds.), Children of depressed parents: Mechanisms of risk and implications for treatment (pp. 203-225). Washington, DC: American Psychological Association. doi:10.1037/10449-008

Ramchandani, P., Stein, A., Evans, J., O’Connor, T. G., \& the ALSPAC Study Team. (2005). Paternal depression in the postnatal period and child development: A prospective population study. The Lancet, 365(9478), 2201-2205. doi:10.1016/S0140-6736(05)66778-5

Rutter, M. (1990). Commentary: Some focus and process considerations regarding effects of parental depression on children. Developmental Psychology, 26(1), 60-67. doi:10.1037/h0092669

Tamis-LeMonda, C. S., Shannon, J. D., Cabrera, N. J., \& Lamb, M. E. (2004). Fathers and mothers at play with their 2-and 3-year-olds: Contributions to language and cognitive development. Child Development, 75(6), 1806-1820. doi:10.1111/j.1467-8624.2004.00818.x 
Verhoeven, M., Junger, M., van Aken, C., Deković, M., \& van Aken, M. A. G. (2010). Parenting and children's externalizing behavior: Bidirectionality during toddlerhood. Journal of Applied Developmental Psychology, 31(1), 93-105. doi:10.1016/j.appdev.2009.09.002

Wilson, S., \& Durbin, C. E. (2010). Effects of paternal depression on fathers' parenting behaviors: A meta-analytic review. Clinical Psychology Review, 30(2), 167-180. doi:10.1016/ j.cpr.2009.10.007

Wong, S. Y., Lau, E. M., Lynn, H., Leung, P. C., Woo, J., Cummings, S. R., \& Orwoll, E. (2005). Depression and bone mineral density: Is there a relationship in elderly Asian men? Results from Mr. Os (Hong Kong). Osteoporosis International, 16(6), 610-615.

\section{In Korean}

Baik, J. W. (2009). Parenting behaviors and child behaviors problems of depressed and non-depressed mothers: Comparisons between mother's perception and child's perception (Doctoral dissertation). Retrieved from http://www.riss.kr/ link?id=T11551429

Cho, B., Lee, J., Lee, H., \& Kwon, H. (1999). Dimensions and assessment of Korean parenting style. Family and Environment Research, 37(10), 123-133.

Chung, M. J., \& Chun, Y. J. (2005). Effects of the father's experiences from his family-of-origin, marital conflict and childrearing behaviors on his child's behavioral problems as a function of the child's sex. Family and Environment Research, 43(2), 41-55.

Chung, M. J., \& Kim, M. J. (2004). Relationships between children's behavior problems and their perceptions of parental childrearing practices. Korean Journal of Child Studies, 25(5), 11-27.

Hong, S., Park, M, \& Kim, W. (2007). Testing the autoregressive cross-lagged effects between adolescents' internet addiction and communication with parents: Multigroup analysis across gender. Journal of Educational Psychology, 21(1), 129-143.
Huh, C.-A., \& Bae, H. (2018). Longitudinal relationships between fathers' parenting attitude and preschoolers' externalizing behavior problem. Korean Journal of Child Studies, 39(1), 19-33. doi:10.5723/kjcs.2018.39.1.19

Jang, J. Y., Kim, J. H., \& Kim, Y. H (2011). Effects of paternal depression, maternal relationship, and parenting style on problem behaviors in young children. The Journal of Educational Studies, 42(2), 79-107.

Kang, J. H., \& Oh, K. J. (2011). Gender differences in the effects of preschoolers' age, temperament and parenting for internalizing and externalizing problems. The Korean Journal of Women Psychology, 16(1), 1-21.

Kim, J., \& Lee, J. (2005). The relationship between father's participation in child rearing and mother's child rearing stress. Korean Journal of Child Studies, 26(5), 245-261.

Kim, J., Kim, M., \& Hong, S. (2009). Gujobangjeongsigmohyeongeulo nonmun sseugi[구조방정식 모형으로 논문쓰기]. Seoul: Communication Books.

Moon, E.-S. (2007). Relationships between mother's child rearing attitudes and child's adjustment to kindergarten. Korean Journal of Child Studies, 28(4), 145-154.

Oh, K. J., \& Kim, Y. A. (2009). Manual of CBCL 1.5-5 PreschoolCaregiver Form. Seoul: Huno Consulting.

Park, S. Y., \& Lim, H. S. (2000). Attachment representation and marital support as predictors of a mother's parenting. Korean Journal of Child Studies, 21(1), 59-72.

\section{ORCID}

Youngmi Kim https://orcid.org/0000-0001-9394-1990

Hana Song https://orcid.org/0000-0002-7745-7303
Received April 30, 2018 Revision received June 4, 2018 Accepted June 11, 2018 